\title{
A Mark-recapture Technique for the Dutch Elm Disease Vector the Native Elm Bark Beetle, Hylurgopinus rufipes (Coleoptera: Scolytidae)
}

\author{
Irene Pines and Richard Westwood
}

\begin{abstract}
Six mark-recapture experiments were conducted in Manitoba, Canada, to determine the effectiveness of fluorescent powder to mark emerging native elm bark beetle adults, Hylurgopinus rufipes (Eichoff) (Coleoptera: Scolytidae), the vector of Dutch elm disease, Ophiostoma novo-ulmi (Brazier), after departure from overwintering sites in spring and emergence from broodwood in summer. Native elm bark beetles marked themselves on emergence from overwintering sites and summer trap logs. The spring and summer periods of flight activity for unmarked and marked beetles were similar. Marked beetles were captured over 1 month after peak emergence in the spring and 2 months after emergence from trap logs in the summer. Marked beetles were captured up to $1 \mathrm{~km}(0.6 \mathrm{mi})$ from release sites. Where integrated Dutch elm disease management activities are implemented in buffer zones to minimize the number of elm bark beetles entering community urban forests, buffer zones should be a minimum of $1 \mathrm{~km}(0.6 \mathrm{mi})$ in width.
\end{abstract}

Key Words. Dutch elm disease; Hylurgopinus rufipes; IPM; marking; plant health care; Scolytidae.

The native elm bark beetle, Hylurgopinus rufipes (Eichoff) (Coleoptera: Scolytidae), is the main vector of Dutch elm disease, Ophiostoma novo-ulmi (Brazier), or variant strains in Manitoba (Brazier 1991; Westwood 1991). Beetles overwinter as adults at the base of healthy American elm [Ulmus americana L. (Ulmaceae)] or Siberian elm [Ulmus pumila L. (Ulmaceae)] trees (Strobel and Lanier 1981; Anderson and Holliday 2003). In the spring, adult beetles emerge from overwintering sites and fly to the branches of healthy or recently stressed elms to feed. After feeding, they move into larger diameter branches or stems of dead or dying elm trees to construct brood galleries and lay eggs (Kaston 1939; Whitten 1964; Thompson and Matthysse 1972; Lanier 1982; Swedenborg et al. 1988; Pines and Westwood 1996). Adult native elm bark beetles sometimes feed on the main branches of living elms in the fall before overwintering (Gardiner 1981). Adults emerging from overwintering sites or summer broodwood may carry spores of O. novo-ulmi on their body and it is during their feeding activity that the inoculum can be introduced into the xylem of healthy elms (Gardiner 1981). McLeod et al. (2005) found that O. novo-ulmi metabolically manipulates an infected elm to increase production of four semiochemicals, thus enhancing the trees' attractiveness to the native elm bark beetle and increasing inoculum dispersal.

The distance a native elm bark beetle will fly to elm trees or elm brood material is not well documented. Kaston (1939) used elm trap logs in two elm-free areas and captured several native elm bark beetles up to $1.6 \mathrm{~km}(1 \mathrm{mi})$ from the nearest elms, but suggested the adults may have traveled farther. Kaston (1939) also indicated that emerging native elm bark beetles will not attempt to fly long distances if satisfactory elm material is nearby. Gardiner (1981) monitored an elm forest in Sault Ste. Marie, Ontario, Canada, and found that a population of native elm bark beetles remained sedentary in an elm stand for several years until the majority of elms perished from Dutch elm disease.
Subsequently, a mass migration of native elm bark beetles occurred in the late summer and fall, presumably when adults went in search of living elms in which to feed and overwinter. Anderbrant and Schlyter (1987) examined the dispersal behavior of two Dutch elm disease vectors in Sweden, the large elm bark beetle (Scolytus scolytus [F.]) and Scolytus laevis (Chap.). They reported that beetles seldom dispersed more than $50 \mathrm{~m}(165 \mathrm{ft})$ from infested elm stands over a period of several years. Birch et al. (1981) found that the smaller European elm bark beetle, Scolytus multistriatus (Marsh.), was able to fly $8 \mathrm{~km}$ (4.8 mi) from the nearest elm to baited sticky traps in remote communities in California, U.S. None of these studies actually used marked beetles; thus, it is impossible to determine the proportion of trapped beetles that originated from study sites or the actual distance beetles moved. The dispersal activity of the native elm bark beetle in North America in the spring and late summer feeding periods is poorly understood. In Manitoba, buffer zones (containing forested areas) of varying widths up to several kilometers wide around many towns and cities have been established and targeted for intensive integrated Dutch elm disease management activities to minimize the number of elm bark beetles entering community urban forests (Westwood 1991). Typically these activities include ground survey, sanitation, and trunk basal insecticide application. Currently there are no data available to guide forest managers implementing Dutch elm disease management programs regarding the optimum width of buffer zones or the distance beetles may move into protected urban forests.

Many mark-recapture studies designed to track bark beetle dispersal have used fluorescent powders to mark adults (Linton et al. 1987; Shore and McLean 1988; Salom and McLean 1991; Cook and Hain 1992). Cook and Hain (1992) found that marking southern pine beetle, Dendroctonus frontalis (Zimm.), and southern pine engraver, Ips gradicollis (Eichh.), with fluorescent powders resulted in no adverse effects on flight initiation or 
semiochemical perception but that marking did shorten the adult lifespan. They also found that $99 \%$ of the bark beetles emerging from fluorescent-powdered brood logs became self-marked and these marks would remain under dry conditions. Linton et al. (1987) applied fluorescent powder to the bases of pine brood trees and brood logs before mountain pine beetle, Dendroctonus ponderosae Hopkins, emergence. They found the emerging adults easily marked themselves in a similar fashion as those treated in vacuum dusters. Numerous studies, including Shore and McLean (1988), Salom and McLean (1991), Safranyik et al. (1992), Franklin and Grégoire (1999), Franklin et al. (2000), Dodds and Ross (2002), and Hansen and Bentz (2003), have also used fluorescent powder marking techniques to successfully track the movements of adult bark- and wood-boring beetles. In most studies, beetles were trapped with either passive or semiochemical baited sticky traps (Dodds and Ross 2002; Hansen and Bentz 2003). There are no published studies examining the effectiveness of fluorescent powders for marking Hylurgopinus rufipes. The objectives of this study were: 1) to determine whether fluorescent powder would mark emerging native elm bark beetle adults; 2) to define patterns of capture of beetles marked by fluorescent powder; and 3) to determine the distance marked beetles dispersed after spring and summer emergence.

\section{MATERIALS AND METHODS}

Two areas with dense populations of American elm and native elm bark beetle were assessed over a 3-year period. The first location, approximately 4 ha $(10 \mathrm{ac})$ of contiguous forest, was used in 1994 and 1995 and was situated along the Red River near Glenlea, Manitoba $\left(49^{\circ} 50^{\prime} 15^{\prime \prime} \mathrm{N}, 95^{\circ} 10^{\prime} 12^{\prime \prime} \mathrm{W}\right)$. The second location, a farm approximately 255 ha (637.5 acres) with a large 44 ha $(110 \mathrm{ac})$ contiguous forest and adjacent open fields, was used in 1996 and situated along the Assiniboine River near Rosedale, Manitoba $\left(49^{\circ} 30^{\prime} 22^{\prime \prime} \mathrm{N}, 9^{\circ} 30^{\prime} 25^{\prime \prime} \mathrm{W}\right)$. Both sites, located in floodplain deciduous forests, were composed mainly of unevenly aged populations of American elm, ash (Fraxinus spp. [Oleaceae]), Manitoba maple (Acer negundo [L.] [Aceraceae]), and Bur oak (Quercus macrocarpa [Michx.] [Fagaceae]).

The study was divided into two separate adult mark and recapture periods: spring emergence from overwintering sites at the base of healthy elms and summer emergence after brood development in trap logs. The fluorescent powder, Day-Glo ArcYellow (AX-16) ${ }^{\circledR}$, purchased from A.R. Monteith (77) Ltd., Toronto, was used in both adult dispersal periods. A dissection microscope and a UVS 12 short-wave fluorescent tube provided magnification and illumination to identify powdered, marked native elm bark beetles caught on sticky traps and Tanglefoot ${ }^{\circledR}$ bands. Preliminary laboratory investigation showed the powder could be easily detected on marked beetles.

\section{Spring Emergence}

Before adult emergence in late May, up to five mature elm trees each greater than $18 \mathrm{~cm}$ (7.2 in) diameter at breast height (dbh) and spaced 3 to $5 \mathrm{~m}$ (9.9 to $16.5 \mathrm{ft}$ ) apart were located in the center of the marking site. Each tree was coated with fluorescent powder on the bottom $1.3 \mathrm{~m}(4.3 \mathrm{ft})$ of the trunk. After treatment, Scout ${ }^{\circledR}$ or Delta ${ }^{\circledR}$ passive sticky traps, purchased from Great Lakes IPM, Vestaburg, Michigan, U.S., were stapled at a height of 1.5 to $2.0 \mathrm{~m}$ ( 5 to $6.6 \mathrm{ft}$ ) on each powdered tree to capture marked beetles emerging from overwintering sites at the tree base. Sticky traps on powdered trees were collected and replaced with new ones on a weekly basis throughout the active flight period from May until late July. Each year, sticky traps were also placed on live elms at varying distances radiating from the center of the marking site in the four cardinal compass directions when possible (Table 1). The maximum trapping distance was increased in successive years (Table 1) after it was demonstrated that marked beetles could be collected at the maximum distance of the trial in the previous year. Actual trap distances from the center of the marking site were determined by the presence of elm trees. As a result of a lack of suitable trees, not all distances or directions were sampled equally each year. The experimental design and the scattered distribution of elm trees prevented a robust statistical assessment of beetle flight distance and direction.

\section{Summer Emergence}

During early June each year, elm trap logs were placed in the stand to be colonized by native elm bark beetles. Trap logs were initially situated in an area of forest distant from the spring marking sites. All logs were approximately $1 \mathrm{~m}(3.3 \mathrm{ft})$ in length and 15 to $20 \mathrm{~cm}$ (6 to 8 in) in diameter. After colonization had occurred by the end of July, each trap log was transported and then thoroughly powdered, piled, and loosely covered by a waterproof tarp at the center of the marking site. After this, Scout ${ }^{\circledR}$ or Delta ${ }^{\circledR}$ passive sticky traps in 1994 and 1995, and Tanglefoot ${ }^{\circledR}$ bands in 1996, were placed on live elm trees at varying distances in four cardinal compass directions. Like in the spring experiments, actual trap distances from the center of the release site were dictated by the presence of live elm trees and as a result of forest gaps, not all distances or directions were sampled equally.

Table 1. Summary statistics for spring and summer marking experiments 1994 to 1996.

\begin{tabular}{|c|c|c|c|c|c|c|c|}
\hline \multirow[b]{2}{*}{ Year } & \multirow[b]{2}{*}{ Date of powder } & \multirow{2}{*}{$\begin{array}{l}\text { Total no. of } \\
\text { powdered trees }\end{array}$} & \multirow{2}{*}{$\begin{array}{l}\text { Total no. of } \\
\text { traps }\end{array}$} & \multirow{2}{*}{$\begin{array}{l}\text { Mean } \pm \text { SEM } \\
\text { tree dbh }(\mathrm{cm})\end{array}$} & \multirow{2}{*}{$\begin{array}{l}\text { Maximum distance of } \\
\text { traps }(\mathrm{m})\end{array}$} & \multicolumn{2}{|c|}{ Total no. of beetles collected } \\
\hline & & & & & & Marked & Unmarked \\
\hline \multicolumn{8}{|c|}{ Spring experiments } \\
\hline 1994 & 28 April & 4 & 24 & $22.2 \pm 1.3$ & 30 & 59 & 128 \\
\hline 1995 & 8 May & 3 & 31 & $18.1 \pm 0.9$ & 50 & 82 & 797 \\
\hline 1996 & 10 May & 5 & 37 & $34.2 \pm 1.3$ & 1000 & 136 & 1491 \\
\hline \multicolumn{8}{|c|}{ Summer experiments } \\
\hline 1994 & 21 July & $28^{z}$ & 12 & $24.4 \pm 1.6$ & 20 & 15 & 283 \\
\hline 1995 & 31 July & $24^{\mathrm{z}}$ & 24 & $19.3 \pm 0.9$ & 100 & 16 & 911 \\
\hline 1996 & 25 July & $68^{\mathrm{z}}$ & 28 & $30.5 \pm 2.3$ & 1000 & 64 & 20601 \\
\hline
\end{tabular}

${ }^{\mathrm{z}}$ Number of trap logs.

$\mathrm{dbh}=$ diameter at breast height. 
Trap distances from the center release site increased for each summer marking experiment and the dbh recorded for trees with sticky traps and Tanglefoot ${ }^{\circledR}$ bands (Table 1). In July 1996, polyethylene bands covered in Tanglefoot ${ }^{\circledR}$ adhesive were used in an attempt to increase the number of beetles collected in the study (LaFrance and Westwood 2006). Traps and bands were changed on a monthly basis when possible and were removed at the end of October or early November. Trap logs were also removed from the field sites at this time and placed in cool storage until dissection could occur. Exit holes were counted and the number of adult brood galleries formed was determined for all logs used in 1994 and 1995. In 1996, 11 of the 68 logs were assessed as a result of time constraints.

After Scout ${ }^{\circledR}$ or Delta ${ }^{\circledR}$ sticky traps and Tanglefoot ${ }^{\circledR}$ bands were removed from trap trees in the spring and summer experiments, the number of marked and unmarked beetles per sample date was counted. Several sticky traps and Tanglefoot ${ }^{\circledR}$ bands were selected and assessed for beetle distribution on the sticky surface. The relationship of tree size (dbh) and number of beetles captured per trap or band was examined to determine if tree diameter influenced capture rate. Analysis with Spearman rank order correlations showed no significant relationship between tree dbh and number of beetles caught per sticky trap or Tanglefoot $^{\circledR}$ band for all spring and summer release experiments. An unpaired t-test was used to compare the percentage of marked beetles caught near the center of the sites (within $20 \mathrm{~m}$ [66 ft] of marked trees) between the spring and summer experiments (Zar 1996). Analysis of variance was used to determine if there were differences in the number of beetle exit holes and brood galleries between years in trap logs. Before data analysis, the assumptions of normality and homogeneity for the variables of trap log surface area, number of exit holes, and number of brood galleries were tested by examining normal probability plots and inspecting graphs of residuals from a general linear model estimate against predicated values. Heterogeneity of residuals was found for all three variables and these were log-transformed to meet the requirements of a normal distribution (Zar 1996). All results are reported without transformation (actual values are shown in tables and figures) and an alpha value of $P \leq 0.05$ was considered significant for all statistical analyses. SPSS ${ }^{\circledR}$ for Windows, release 11 (SPSS Inc., Chicago, IL) was used for statistical analyses.

\section{RESULTS AND DISCUSSION}

Native elm bark beetles were caught on traps starting 20 May, 29 May, and 23 May in 1994, 1995, and 1996, respectively (Figure 1). Peak flight activity occurred from 20 to 27 May, 6 June, and 7 June in 1994, 1995, and 1996, respectively. Marked beetles were captured on traps for each collection date in all 3 years except on 27 June 1995 (Figure 2). The length of time unmarked and marked beetles were collected was generally similar. Marked beetles were captured at the maximum distances from trap trees of $30 \mathrm{~m}(99 \mathrm{ft})$ in $1994,50 \mathrm{~m}(165 \mathrm{ft})$ in 1995 , and up to $750 \mathrm{~m}(2475 \mathrm{ft})$ in the spring of 1996 (Figure 3).

For summer emergence experiments, native elm bark beetles were caught on traps or bands starting 27 July, 10 August, and 19 September in 1994, 1995, and 1996, respectively (Figure 4). The majority of beetles were captured in August in 1994 and 1995 and in October in 1996. Marked beetles were captured on traps for the majority of collection dates in all 3 years (Figure 5). Dates with no captures of marked beetles were 27 October 1994

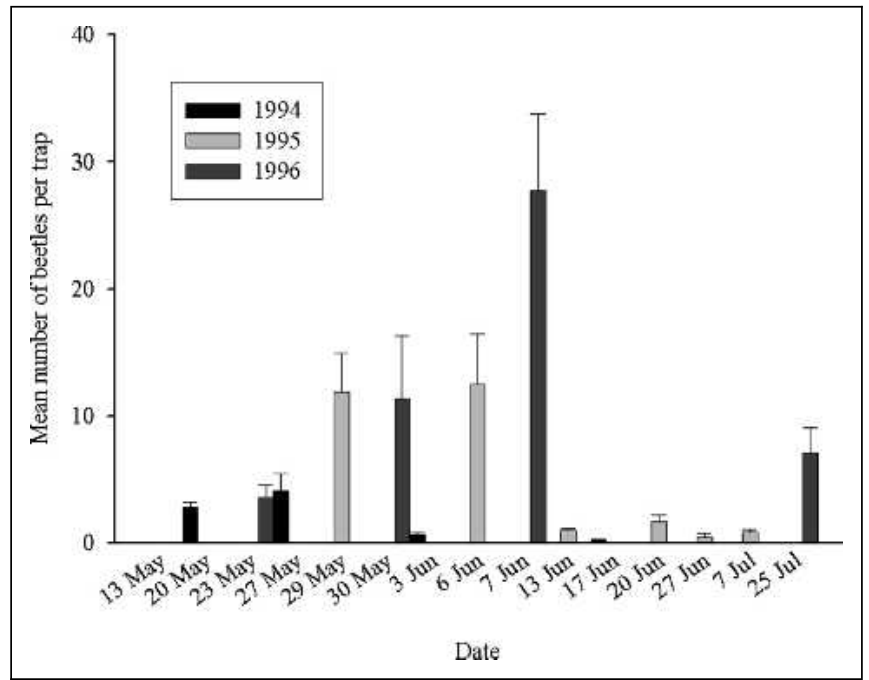

Figure 1. Capture of native elm bark beetles ( \pm SEM) during spring emergence.

and in 1995, 13 and 29 September and 1 November. After emerging from the powdered trap logs, marked beetles were captured at the maximum distances from the release sites each year: $20 \mathrm{~m}(66 \mathrm{ft})$ in 1994, $100 \mathrm{~m}(330 \mathrm{ft})$ in 1995 , and $1000 \mathrm{~m}$ $(3,300 \mathrm{ft})$ in 1996) (Figure 6). There was no significant difference in the percentage of total marked beetles captured $20 \mathrm{~m} \mathrm{(66}$ $\mathrm{ft}$ ) or less from the center of the release sites between the spring $(1994,1995,1996)$ and summer $(1994,1995,1996)$ experiments (spring $=89.2 \%$, summer $\left.=66.5 \%, t_{3}=2.09, P=0.128\right)$.

There were 4,195 and 4,977 beetle exit holes in all trap logs dissected in 1994 and 1995, respectively, whereas only a portion of the trap logs were dissected in 1996 . There was no significant difference in the mean trap log surface area of individual logs between years $\left(F_{2,62}=1.04, P=0.359\right.$, Table 2$)$ and no difference in the mean number of exit holes in trap logs between years $\left(F_{2,62}=0.22, P=0.797\right.$, Table 2$)$. There were significantly more brood galleries formed in trap logs in the 1996

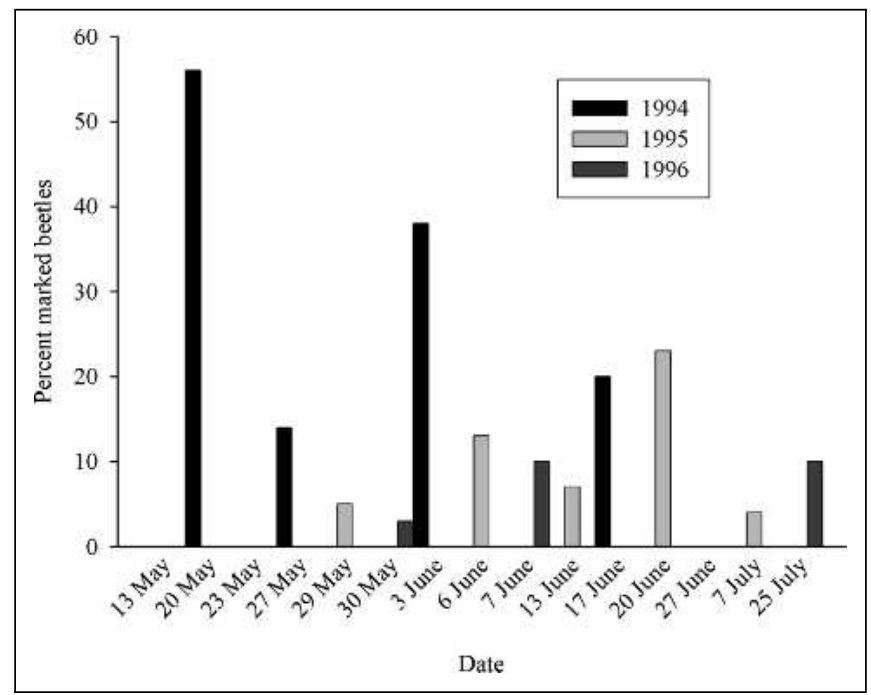

Figure 2. Percent of all native elm bark beetles marked and captured during spring emergence. 


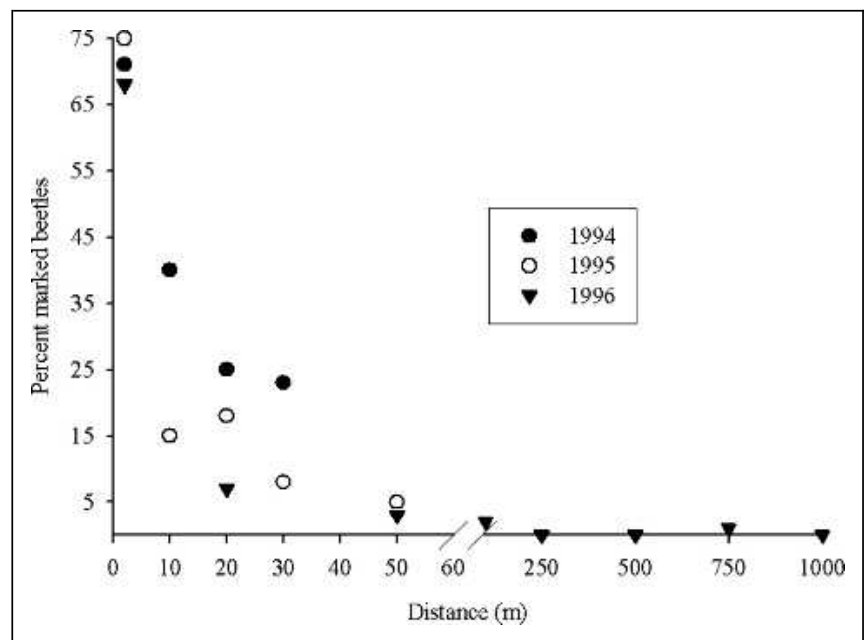

Figure 3. Percent of all native elm bark beetles marked and captured at increasing distances from the spring emergence sites.

experiment versus the 1994 and 1995 experiment $\left(F_{2,60}=8.45\right.$, $P<0.001$, Table 2). In the 1994 and 1995 summer marking experiments, 15 and 16 marked beetles, respectively, were captured (Table 1). Given that there were over 4,000 total exit holes in trap logs in both 1994 and 1995, a very small percentage of potentially marked beetles were captured. Similarly in other mark and recapture experiments, recapture rates were generally very low (Shore and McLean 1988; Salom and McLean 1991).

Tanglefoot ${ }^{\circledR}$ bands used in Fall 1996 caught the highest number of beetles,although they were not tested in comparison with either the Scout ${ }^{\circledR}$ or Delta ${ }^{\circledR}$ sticky traps (Table 1). Because the beetles appeared to be caught in the uppermost portion of the bands, several Tanglefoot ${ }^{\circledR}$ bands were examined to determine where the adults were located and of the 2,737 beetles caught, $92 \%$ were located within the top $3 \mathrm{~cm}$ (1.2 in) of the band. The other $8 \%$ were found randomly scattered on the remaining $7 \mathrm{~cm}$ (2.8 in) of the band surface. Visual examination of the Scout ${ }^{\circledR}$ and Delta ${ }^{\circledR}$ sticky traps used in Fall 1994 and 1995 indicated that beetles were randomly scattered across the surface of the traps.

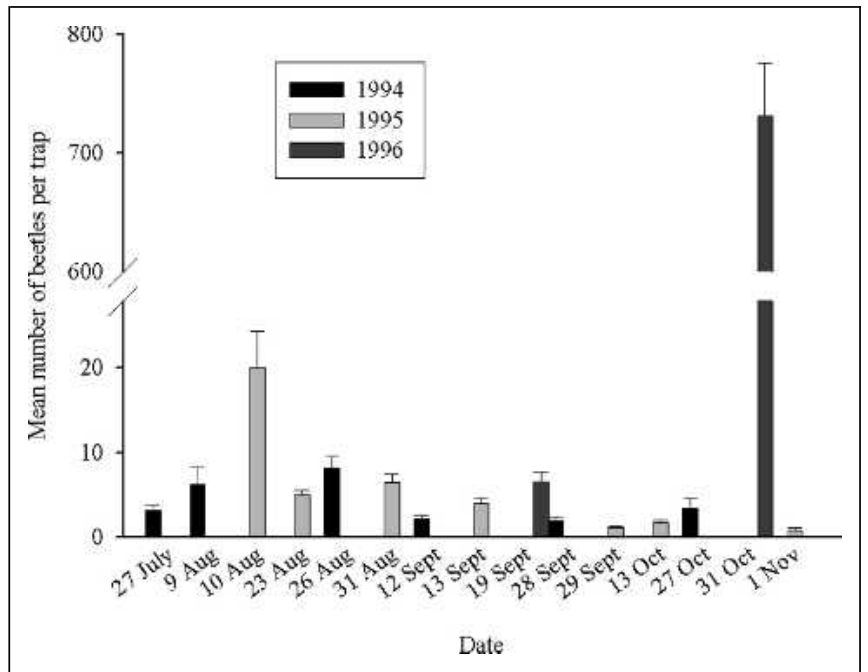

Figure 4. Capture of native elm bark beetles ( \pm SEM) during summer emergence.

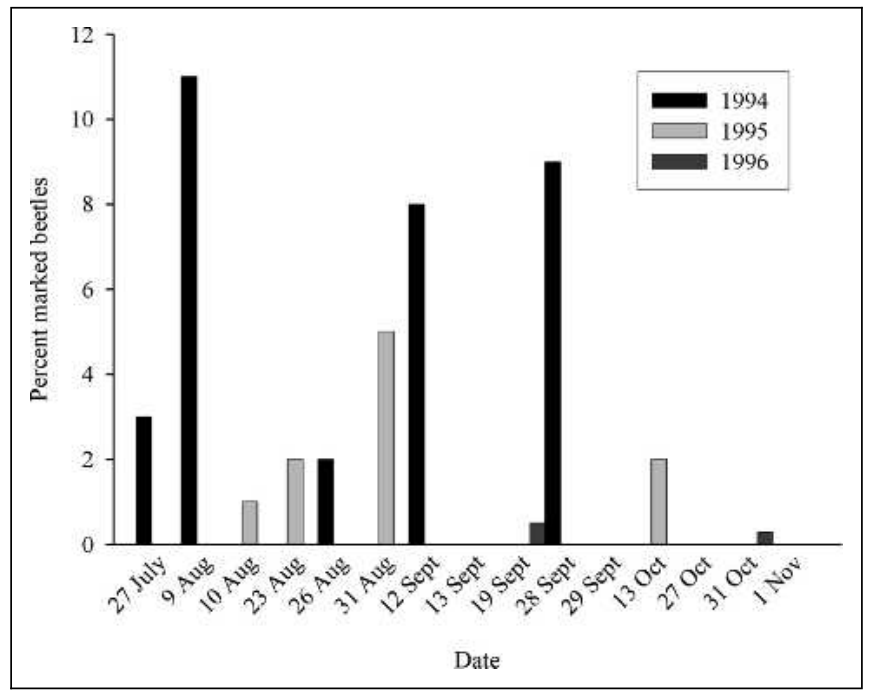

Figure 5. Percent of all native elm bark beetles marked and captured during summer emergence.

Native elm bark beetles marked themselves on emergence from their overwintering sites and trap logs. The powdered adult beetles were easily identified with the ultraviolet lamp on both the Scout ${ }^{\circledR}$ and Delta ${ }^{\circledR}$ sticky traps and Tanglefoot ${ }^{\circledR}$ bands used in the study. Marked beetles were captured over a 2-month period in the spring and over a 3-month period after emergence from trap logs in summer. After leaving overwintering sites, the native elm bark beetle flight period peaked in late May or early June each year of the study. Most (greater than $80 \%$ ) of the marked spring beetles were trapped in late May (1994) or in early June (1995 and 1996) in this study. This active period is later than in Minnesota where Landwehr et al. (1982) and Swedenborg et al. (1988) reported native elm bark beetles active in April. The cooler climate in Manitoba may influence the delayed onset of spring emergence activity that subsequently results in a later flight period. The spring emergence period in the Manitoba experiments ranged from 4 to 8 weeks with some marked adults captured into July. The spring emergence period in Manitoba is

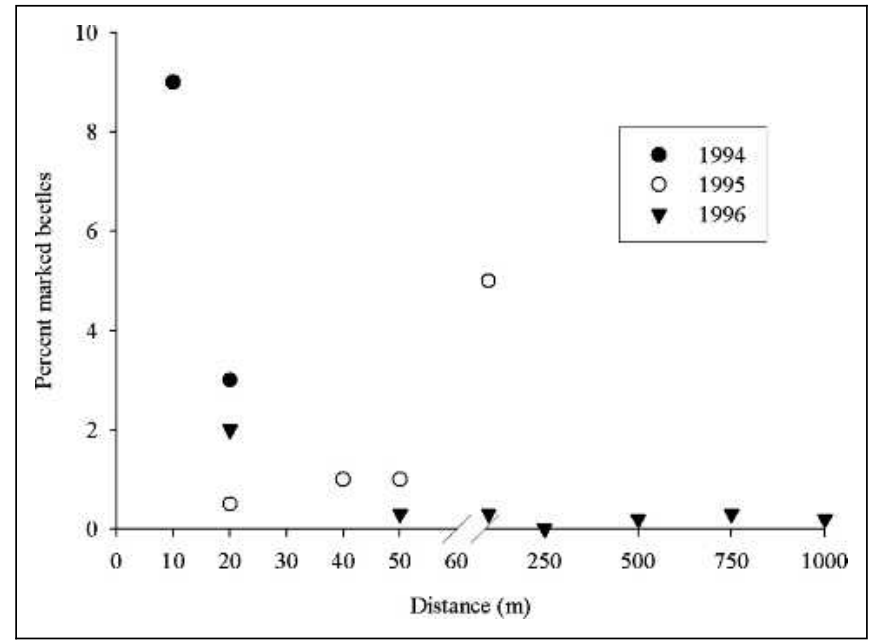

Figure 6. Percent of all native elm bark beetles marked and captured at increasing distances from the summer emergence sites. 
Table 2. Trap log surface area, number of exit holes, and brood galleries by year for spring and summer marking experiments 1994 to 1996.

\begin{tabular}{|c|c|c|c|c|c|}
\hline Year & $\begin{array}{l}\text { No. of } \\
\text { trap logs }\end{array}$ & $\begin{array}{l}\text { Mean } \pm \text { SEM trap } \log \\
\text { surface area }\left(\mathrm{cm}^{2}\right)\end{array}$ & $\begin{array}{l}\text { Total no. } \\
\text { of exit holes }\end{array}$ & $\begin{array}{l}\text { Mean } \pm \text { SEM } \\
\text { no. of exit holes }\end{array}$ & $\begin{array}{l}\text { Mean } \pm \text { SEM } \\
\text { no. of brood galleries }\end{array}$ \\
\hline 1994 & 28 & $1501.1 \pm 79.4$ & 4195 & $149.8 \pm 19.7$ & $32.7 \pm 6.6$ \\
\hline 1995 & 24 & $1409.4 \pm 85.2$ & 4977 & $207.4 \pm 31.3$ & $66.9 \pm 12.4$ \\
\hline 1996 & $11^{\mathrm{z}}$ & $1614.6 \pm 149.6$ & 1383 & $125.7 \pm 16.4$ & $129.6 \pm 27.8$ \\
\hline
\end{tabular}

${ }^{2}$ Total of 68 logs used, 11 dissected.

consistent with Swedenborg et al. (1988) who described a 6-week period of spring emergence for $H$. rufipes. Because the actual emergence dates of individual beetles could not be determined, it is impossible to predict how long marked beetles had been active at the date of capture. There was little evidence of marking powder on trees in the spring experiments by the end of May; thus, based on the July captures, it is conceivable that marked beetles lived 1 month or more after emergence in the spring. The summer trap logs were protected from weathering for several months. It is difficult to determine how long marked beetles were active in fall. Future research should examine a narrower window of emergence to determine actual lengths of flight periods for beetles.

There was a low recapture rate, especially when examining the Summer 1994 and 1995 marked beetle captures in comparison to the exit hole counts. Low marked beetle capture rates may have been the result of low marking effectiveness of the powder or we simply did not capture a greater portion of marked beetles.

In 1994 and 1995, marked adults were captured at all trapping distances in both spring and summer experiments. Many marked beetles were caught near the marking sites after emerging from tree bases or summer brood material. Similarly, Swedenborg et al. (1988) found that beetles land on nearby trees after emergence before flying again. Kaston (1939) also suggested that emerging beetles will not attempt to fly long distances if satisfactory elm material is nearby. Our study found no significant difference in the percentage of marked beetles caught $20 \mathrm{~m} \mathrm{(66}$ $\mathrm{ft}$ ) or less from the center of the marking sites in the spring and summer experiments.

In Summer/Fall 1996, Tanglefoot ${ }^{\circledR}$ bands captured greater numbers of beetles in comparison to the Scout ${ }^{\circledR}$ and Delta ${ }^{\circledR}$ sticky traps used in previous experiments. The majority of beetles caught in the Summer 1994 and 1995 experiments were captured in August after which adult captures declined. Swedenborg et al. (1988) also reported that sticky trap captures diminished in September. The dense beetle numbers on the top portion of Tanglefoot ${ }^{\circledR}$ bands used in 1996 suggests bark beetles may be walking down the bole of the tree to construct overwintering sites at the base of elm trees. Anderson (1996) found that after a frost event in which temperatures fell between $-6^{\circ} \mathrm{C}\left(42.8^{\circ} \mathrm{F}\right)$ to $-10^{\circ} \mathrm{C}\left(50^{\circ} \mathrm{F}\right)$ in late October, there immediately followed a major increase in overwintering activity by native elm bark beetles. The Scout ${ }^{\circledR}$ and Delta ${ }^{\circledR}$ sticky traps may be more efficient in capturing adults during the spring and early summer months when the beetles are actively flying rather than in the fall when temperatures are cooler. The complete encirclement of the tree by the Tanglefoot ${ }^{\circledR}$ band may also facilitate a higher capture rate of crawling beetles than the Scout ${ }^{\circledR}$ and Delta ${ }^{\circledR}$ sticky traps used.

There were many live elm trees remaining in the forest stands at the conclusion of each experiment and most marked beetles were caught within $20 \mathrm{~m}(66 \mathrm{ft})$ from release trees. Beetles may have remained in the sites to feed or overwinter on the remaining live elm trees. Anderbrant and Schlyter (1987) found European Dutch elm disease vectors seldom dispersed more than $50 \mathrm{~m}$ $(165 \mathrm{ft})$ from infested elm stands over a period of several years, but did not report on beetle movement once host trees became scarce and did not mark beetles. Research using mark and recapture techniques is needed to determine if the dispersal behavior of the adult beetles changes as the percentage of live elm trees declines in a stand. It is important to determine if marking techniques can be used to accurately track mass migrations of adults once hosts become scarce. Results from this study demonstrate that beetles can be easily marked and tracked. Experiments within buffer zones or forest edges surrounding towns and cities where Dutch disease management is practiced may be appropriate to determine if significance numbers of elm bark beetles are entering community urban forests (Westwood 1991). If a suite of management techniques (including survey, beetle control, and sanitation) is effectively carried out in buffer zones, the incidence of beetle movement into urban forests should be minimized. Future research should also investigate the effectiveness of Tanglefoot ${ }^{\circledR}$ bands as an efficient monitoring tool to further elucidate the movement of beetles on tree trunks.

Acknowledgments. We thank T. Paton and N. Normandeau for technical assistance and two anonymous reviewers for improving the manuscript. Funding was provided by Manitoba Conservation, Forestry Branch, Government of Manitoba, and the Centre for Forest Interdisciplinary Research, University of Winnipeg.

\section{LITERATURE CITED}

Anderbrant, O., and F. Schlyter. 1987. Ecology of the Dutch elm disease vectors Scolytus laevis and S. scolytus (Coleoptera: Scolytidae) in southern Sweden. Journal of Applied Ecology 24:539-550.

Anderson, P.L. 1996. Overwintering behaviour of the native elm bark beetle, Hylurgopinus rufipes (Eichhoff) (Coleoptera: Scolytidae), in Manitoba. MSc Thesis, University of Manitoba. pp. 1-109.

Anderson, P.L., and N.J. Holliday. 2003. Distribution and survival of overwintering adults of the Dutch elm disease vector, Hylurgopinus rufipes (Coleoptera: Scolytidae), in American elm trees in Manitoba. Agricultural and Forest Entomology 5:137-144.

Birch, M.C., T.D. Paine, and J.C. Miller. 1981. Effectiveness of pheromone mass-trapping of the smaller European elm bark beetle. California Agriculture 35:6-7.

Brazier, C.M. 1991. Ophiostoma novo-ulmi sp. nov. causative agent of the current Dutch elm disease pandemics. Mycopathologia 115: $151-161$

Cook, S.P., and F.P. Hain. 1992. The influence of self-marking with fluorescent powders on adult bark beetles (Coleoptera: Scolytidae). Journal of Entomological Science 27:269-279. 
Dodds, K.J., and D.W. Ross. 2002. Sampling range and range of attraction of Dendroctonus pseudotsugae pheromone-baited traps. The Canadian Entomologist 134:343-355.

Franklin, A.J., C. Debruyne, and J.C. Grégoire. 2000. Recapture of Ips typographus L. (Col., Scolytidae) with attractants of low release rates: Localized dispersion and environmental influences. Agricultural and Forest Entomology 2:259-270.

Franklin, A.J., and J.C. Grégoire. 1999. Flight behaviour of Ips typographus L. (Col., Scolytidae) in an environment with pheromones. Annals of Science 56:591-598.

Gardiner, L.M. 1981. Seasonal activity of the native elm bark beetle, Hylurgopinus rufipes, in central Ontario (Coleoptera: Scolytidae). The Canadian Entomologist 113:341-348.

Hansen, E.W., and B.J. Bentz. 2003. Comparison of reproductive capacity among univoltine, semivoltine, and re-emerged parent spruce beetles (Coleoptera: Scolytidae). The Canadian Entomologist 135: 697-712.

Kaston, B.J. 1939. The native elm bark beetle Hylurgopinus rufipes (Eichhoff) in Connecticut. Connecticut Agricultural Experiment Station Bulletin 420:1-39.

LaFrance, K.E., and A.R. Westwood. 2006. An assessment of tree banding techniques to capture cankerworm defoliators of elm and ash trees in Winnipeg, Manitoba, Canada. Arboriculture and Urban Forestry 32:10-17.

Landwehr, V.R., W.J. Phillipsen, and M.E. Ascerno. 1982. An integrated approach to managing native elm bark beetle populations in Minnesota. In Kondon, E.S., Y. Hiratsuka, and W.B.G. Denyer (Eds.). Proceedings of the Symposium and Workshop on Dutch Elm Disease, Winnipeg, Manitoba, 5-9 October 1981. Environment Canada and Manitoba Department Natural Resources. pp. 454-465.

Lanier, G.N. 1982. Behavior-modifying chemicals in Dutch elm disease vector control. In Kondon, E.S., Y. Hiratsuka, and W.B.G. Denyer (Eds.). Proceedings of the Symposium and Workshop on Dutch Elm Disease, Winnipeg, Manitoba, 5-9 October 1981. Environment Canada and Manitoba Department Natural Resources. pp. 371-394.

Linton, D.A., L. Safranyik, L.H. McMullen, and R. Betts. 1987. Field Techniques for rearing and marking mountain pine beetle for use in dispersal studies. Journal of Entomological Science British Columbia 84:53-57.

McLeod, G., R. Gries, S.H. von Reub, J. Rahe, R. McIntosh, W.A. Konig, and G. Gries. 2005. The pathogen causing Dutch elm disease makes host trees attract insect vectors. Proceedings of the Royal Society of London. Series B. Biological Sciences 272:2499-2503.

Pines, I.L., and A.R. Westwood. 1996. Evaluation of monosodium methane arsenate for the suppression of native elm bark beetles, Hylurgopinus rufipes (Eichhoff) (Coleoptera: Scolytidae). The Canadian Entomologist 128:435-441.

Safranyik, L., D.A. Linton, R. Silversides, and L.H. McMullen. 1992. Dispersal of released mountain pine beetles under the canopy of a mature lodgepole pine stand. Journal of Applied Entomology 113: 441-450.

Salom, S.M., and J.A. McLean. 1991. Environmental influences on dispersal of Trypodendron lineatum (Coleoptera: Scolytidae). Environmental Entomology 20:565-576.

Shore, T.L., and J.A. McLean. 1988. The use of mark-recapture to evaluate a pheromone-based mass trapping program for ambrosia beetles in a sawmill. Canadian Journal of Forest Research 18: 1113-1117.

Strobel, G.A., and G.N. Lanier. 1981. Dutch elm disease. Scientific American 245:56-66.

Swedenborg, P.D., R.L. Jones, M.E. Ascerno, and V.R. Landwehr. 1988. Hylurgopinus rufipes (Eichh.) (Coleoptera: Scolytidae): Attraction to broodwood, host colonization behavior, and seasonal activity in central Minnesota. The Canadian Entomologist 120:1041-1050.
Thompson, H.E., and J.G. Matthysse. 1972. Role of the Native Elm Bark Beetle Hylurgopinus rufipes (Eichh.) in Transmission of the Dutch Elm Disease Pathogen Ceratocystis ulmi (Buisman) C. Moreau. Search (Agriculture Entomology). Vol. 2, No. 1. 16 pp.

Westwood, A.R. 1991. A cost benefit analysis of Manitoba's integrated Dutch elm disease management program 1975-1990. Proceedings of the Entomological Society of Manitoba 47:44-59.

Whitten, R.R. 1964. Elm bark beetles. U.S. Department of Agriculture, Forest Service, Division of Forest Insect Research Leaflet 185 Revised 1963.

Zar, J.H. 1996. Biostatistical Analysis. Prentice-Hall, Upper Saddle River, NJ.

Irene Pines

Manitoba Conservation

Forestry Branch

200 Saulteaux Crescent

Winnipeg, Manitoba, R3J $3 W 3$

Richard Westwood (corresponding author)

University of Winnipeg

Center for Forest Interdisciplinary Research

515 Portage Avenue

Winnipeg Manitoba R3B 2E9, Canada

r.westwood@uwinnipeg.ca

Résumé. Six expériences de captures avec suivis ont été menées au Manitoba (Canada), afin de déterminer l'efficacité de la poudre fluorescente pour marquer les scolytes indigènes de l'orme adultes émergents - Hylurgopinus rufipes (Eichoff) (coléoptères de la famille des Scolytidae) -, soient les vecteurs de la maladie hollandaise de l'orme - Ophiostoma novo-ulmi (Buisman) Nannf. -, et ce après leur départ des sites d'hibernation au printemps et lors de leur émergence de l'intérieur du bois en été. Les scolytes indigènes de l'orme se marquaient d'euxmêmes lors de l'émergence des sites d'hibernation au printemps ainsi que dans des pièges sur le bois en été. Les périodes printanières et estivales d'activité en vol étaient similaires pour les scolytes marqués et ceux non marqués. Les scolytes marqués ont été capturés durant un mois suivant le sommet d'émergence au printemps et sur deux mois suivant l'émergence des pièges dans le bois en été. Les scolytes marqués ont été capturés jusqu'à un kilomètre de distance du lieu de relâchement. Là où des activités de gestion de la maladie hollandaise de l'orme sont implantées dans les zones-tampon pour minimiser le nombre de scolytes de l'orme qui attaquent la forêt urbaine, les zones-tampon devraient être d'au minimum d'un kilomètre de large.

Zusammenfassung. In Manitoba, Kanada, wurden sechs Experimente durchgeführt, um die Effektivität von fluoreszierendem Pulver als Markierung von schlüpfenden Ulmensplintkäfern (Hylurgopinus rufipes (Eichoff) (Coleoptera: Scolytidae), den Überträgern der Ulmenkrankheit (Ophiostoma novo-ulmi (Buisman) Nannf.) nach dem Verlassen der Winterlager im Frühling und dem Erscheinen/Auftreten im Sommer. Die Ulmensplintkäfer markierten sich selbst beim Verlassen der Winterlager und den Lockfallen. Die Frühling- und Sommerperiode der Flugaktivität der markierten und unmarkierten Käfer war identisch. Markierte Käfer wurden einen Monat nach dem Höhepunkt der Schlüpfung im Frühling und zwei Monate nach dem Verlassen der Sommerfallen gefangen. Es wurden bis zu einer Distanz von einem Kilometer von der Schlüpfstelle noch markierte Käfer gefunden. Dort, wo integrierte Ulmenkrankheit-Management-Aktivitäten in Pufferzonen zur Minimierung der Anzahl der Käfer, die bezeichneten Gebiete eindringen, sollten die Pufferzonen mindestens einen Radius von einem Kilometer haben. 
Resumen. Se realizaron seis experimentos en Manitoba, Canadá, para determinar la efectividad de un polvo fluorescente para marcar la emergencia de escarabajos adultos del olmo nativo, Hylurgopinus rufipes (Eichoff) (Coleoptera: Scolytidae), el vector de la enfermedad del olmo holandés, Ophiostoma novo-ulmi (Buisman) Nannf., luego de la salida de los sitios en primavera y emergencia en el verano. Los escarabajos se marcaron a sí mismos una vez emergieron de los sitios y trampas en el verano. Los periodos de primavera y verano de actividad volátil para los escarabajos marcados y no marcado fueron similares. Los escarabajos marcados fueron capturados en el mes siguiente al pico de emergencia en la primavera y dos meses después de la emergencia de las trampas en el verano. Los escarabajos marcados fueron capturados hasta un kilómetro (0.62 millas) de los sitios de dispersión. En las zonas donde se implementaron actividades integradas de manejo de la plaga en áreas amortiguadoras para minimizar el número de escarabajos que entraron a las comunidades de bosques urbanos, estas zonas amortiguadoras deberían tener mínimo un kilómetro en amplitud. 